\title{
EVALUASI KONDISI EKOSISTEM MANGROVE ANGKE KAPUK TELUK JAKARTA DAN KONSEKUENSINYA TERHADAP JASA EKOSISTEM
}

\section{EVALUATING THE CONDITIONS OF ANGKE KAPUK MANGROVE ECOSYSTEM JAKARTA BAY, AND ITS CONSEQUENCES ON ECOSYSTEM SERVICES}

\author{
Achmad Sofian ${ }^{1,2}$, Cecep Kusmana ${ }^{3}$, Akhmad Fauzi $^{4}$, \& Omo Rusdiana ${ }^{3}$
}

\begin{abstract}
${ }^{1}$ Program Studi Ilmu Pengelolaan Sumberdaya Alam dan Lingkungan, Sekolah Pasca Sarjana Institut Pertanian Bogor. ${ }^{2}$ KKD-BP Sosial Ekonomi Perikanan Politeknik Kelautan dan Perikanan Sorong, Kementerian Kelautan dan Perikanan, ${ }^{3}$ Departemen Silvikultur Fakultas Kehutanan, Institut Pertanian Bogor.

${ }^{4}$ Departemen Ekonomi Sumberdaya dan Lingkungan, Fakultas Ekonomi dan Manajemen, Institut Pertanian Bogor.

e-mail : eachmad.sofian@kkp.go.id
\end{abstract}

Diterima tanggal: 19 September 2019 ; diterima setelah perbaikan: 14 Oktober 2019 ; Disetujui tanggal: 17 Oktober 2019 DOI: http://dx.doi.org/10.15578/jkn.v15i1.7722

\begin{abstract}
ABSTRAK
Ekosistem mangrove memiliki sejumlah manfaat dan jasa ekosistem, namun keberadaannya terus memperoleh tantangan dan tekanan akibat aktivitas di wilayah pesisir. Penelitian ini bertujuan menganalisis kondisi ekosistem mangrove dan konsekuensinya terhadap jasa ekosistem di kawasan ekosistem Mangrove Angke Kapuk Teluk Jakarta. Kondisi ekosistem dianalisis dengan mengkaji tutupan lahan dan tingkat kekritisan lahan mangrove menggunakan citra SPOT 6 dan Sistem Informasi Geografi, sedangkan konsekuensinya terhadap jasa ekosistem dikaji dengan analisis deskriptif. Hasil analisis menunjukkan luasan ekosistem Mangrove Angke Kapuk sebesar 291,17 ha dengan tingkat kerapatan 272,79 ha jarang, 16,83 ha sedang dan 1,54 ha lebat. Ekosistem mangrove yang masih terlihat terjaga sebagian besar berada pada kawasan Suaka Marga Satwa Muara Angke dan Hutan Lindung Angke Kapuk, meskipun demikian posisinya sangat dekat dan berada diantara kawasan permukiman dan infrastruktur lainnya. Kondisi kawasan ekosistem Mangrove Angke Kapuk berdasarkan tingkat kekritisan lahan mangrove terkategori rusak 272,79 ha dan 18,38 ha terkategori tidak rusak. Kawasan ekosistem Mangrove Angke Kapuk berpotensi terus mengalami tekanan terutama disebabkan aktivitas dari area terbangun di sekitarnya. Kondisi tersebut juga akan berkonsekuensi terhadap menurunnya jasa ekosistem yang tersedia. Jasa ekosistem mangrove yang sediakala masih dirasakan menjadi semakin berkurang atau bahkan hilang sehingga pada akhirnya dapat menyebabkan ketidaknyamanan, kerugian ekonomi dan ancaman bencana. Keberadaan kawasan ekosistem Mangrove Angke Kapuk di pesisir utara Jakarta perlu mendapat perhatian karena masih berkontribusi memberikan jasa ekosistem dan menjaga kelestarian lingkungan.
\end{abstract}

Kata kunci : jasa ekosistem, mangrove, pesisir, Teluk Jakarta.

\section{ABSTRACT}

Mangrove ecosystems have many benefits and services, but they continue to face challenges and pressures. This study aims to determine the condition of the mangrove ecosystem and its consequences on ecosystem services in the Angke Kapuk Mangrove (MAK) ecosystem area, Jakarta Bay. The ecosystem condition was determined by examining land cover and the critical level of mangrove area using SPOT 6 imagery and GIS, while descriptive analysis was used to assess the consequences on ecosystem services. The results of the analysis showed that the area of MAK ecosystem was 291.17 ha which consists of 272.79 ha low density, 16.83 ha medium density, and 1.54 ha high density. Based on the critical level of the mangrove, 272.79 ha of MAK ecosystem condition is categorized as damage area and 18.38 ha is not damaged. The MAK ecosystem area is potentially experiencing the pressure continuously mainly due to the activities of the built-up area of surround it. The condition will also have an impact on ecosystem services. Ecosystem services of MAK ecosystem area that had been felt in the past, now it becomes diminished or even disappeared so that finally it can cause inconveniences, economic loss and the threat of disasters. The existence of mangrove areas on the coast of Jakarta needs attention because they still provide ecosystem services and preserves the environment.

Keywords: ecosystem services, mangrove, coastal, Jakarta Bay.

Evaluasi Kondisi Ekosistem Mangrove Angke Kapuk Teluk Jakarta dan Konsekuensinya Terhadap Jasa Ekosistem - Achmad Sofian, Cecep Kusmana, Akhmad Fauzi, \& Omo Rusdiana 


\section{PENDAHULUAN}

Ekosistem mangrove merupakan salah satu ekosistem wilayah pesisir yang unik dan dinamis karena berada di wilayah pasang surut peralihan ekosistem darat dan laut (Kusmana, 2015). Eksosistem mangrove memiliki sejumlah manfaat dan jasa (services) bagi kehidupan manusia, diantaranya sebagai pelindung pesisir dari gelombang laut dan intrusi air laut, sebagai tempat mencari makan dan berkembang biak bagi biota seperti ikan, dan sebagai tempat rekreasi (Brander et al., 2012; Malik et al.,2015). Indonesia diketahui memiliki luas mangrove terbesar di dunia yaitu sekitar $26 \%-29 \%$ dari total luasan mangrove dunia (Hamilton \& Casey, 2016) dan keberadannya memberikan manfaat ekologi maupun sosial ekonomi bagi masyarakat sekitar (Malik et al., 2015). Namun demikian, tantangan dan tekanan terhadap ekosistem mangrove terus terjadi seiring pesatnya aktivitas pemanfaatan dan pembangunan di wilayah pesisir.

Ekosistem mangrove mengalami banyak tekanan dan menjadi ekosistem tropik paling terancam di wilayah pesisir (Ahmed \& Glaser, 2016). Tren penurunan luasan mangrove di Indonesia selama kurun waktu tahun 2000-2012 memiliki laju rerata antara 0,26 \% $0,66 \%$ per tahun (Hamilton \& Casey, 2016). Pemanfaatan ekosistem mangrove berlebih seperti pembukaan tambak secara besar-besaran dan konversi lahan mangrove menjadi peruntukan lain menjadi salah satu tekanan terbesar terutama di wilayah pesisir (Brander et al., 2012; Friess \& Webb, 2014). Potensi ancaman degradasi mangrove semakin besar di daerah yang dekat dengan pusat kegiatan ekonomi (Hernandi, et al., 2013). Wilayah pesisir diketahui juga menjadi pusat kegiatan ekonomi dan pembangunan serta peningkatan jumlah penduduk yang pesat. Eksploitasi dan tekanan terhadap ekosistem mangrove secara terus menerus akan berdampak pula pada perubahan kondisi ekosistem dan jasa ekosistem yang dibutuhkan masyarakat. Degradasi dan penurunan luasan mangrove memiliki dampak lingkungan dan sosial ekonomi bagi masyarakat pesisir (Malik et al., 2017). Beberapa penyebab hilangnya hutan mangrove di Indonesia dan seluruh dunia disajikan dalam Tabel 1.

Kondisi ekosistem mangrove penting untuk diketahui karena terkait dengan keberlangsungan dan ketersediaan jasa ekosistem. Jasa ekosistem sangat terkait dengan ekosistem dalam memberikan manfaat bagi kesejahteraan masyarakat (Elliff \& Kikuchi, 2015). Penilaian kondisi hutan mangrove juga sangat penting untuk perencanaan konservasi dan pengelolaan termasuk penelitian dan pengukuran ekonomi dan valuasi (Schmitt \& Duke, 2015). Dukungan data dan informasi spasial dengan penginderaan jauh dapat membantu memberikan gambaran wilayah (Damayanti, et al., 2017) dan kondisi ekosistem mangrove. Prediksi yang akurat terhadap kondisi mangrove dapat mendukung perencanaan yang lebih baik, meminimalkan dan mengantisipasi kerugian, mengurangi ancaman pembangunan pesisir, dan untuk keamanan masyarakat pesisir (Omo-irabor et al., 2011). Studi kondisi ekosistem mangrove ini dapat menjadi informasi mengenai konsekuensi terhadap jasa ekosistemnya yang sangat terkait dengan

Tabel 1. Penyebab hilangnya hutan mangrove di Indonesia dan dunia

Table 1. Causes of mangrove forest loss in Indonesia and worldwide

\begin{tabular}{lll}
\hline $\begin{array}{l}\text { Aktivitas manusia } \\
\text { secara langsung }\end{array}$ & $\begin{array}{l}\text { Aktivitas manusia } \\
\text { secara tidak Langsung }\end{array}$ & Sebab alam \\
\hline $\begin{array}{l}\text { Pengairan untuk pertanian dan } \\
\text { pengendalian nyamuk }\end{array}$ & Pengalihan sedimen dari danau dan banjir & $\begin{array}{l}\text { Kenaikan permukaan air } \\
\text { laut }\end{array}$ \\
$\begin{array}{l}\text { Pengerukan dan perlindungan } \\
\text { banjir }\end{array}$ & $\begin{array}{l}\text { Perubahan aliran air dengan pembangunan } \\
\text { kanal dan jalan }\end{array}$ & Kekeringan \\
$\begin{array}{l}\text { Pembuangan dan penyemprotan } \\
\text { pestisida }\end{array}$ & $\begin{array}{l}\text { salinitas tanah yang meningkat karena perubahan } \\
\text { air menjadi tawar }\end{array}$ & Angin topan dan badai \\
$\begin{array}{l}\text { Konversi lahan mangrove } \\
\text { menjadi tambak udang dan ikan }\end{array}$ & & tropik lainna \\
$\begin{array}{l}\text { Pembangunan dinding laut dan } \\
\text { tanggul }\end{array}$ & & Erosi tan \\
$\begin{array}{l}\text { Pembangunan fasilitas pariwisata } \\
\text { Pengembangan industri dan jalan }\end{array}$ & & \\
$\begin{array}{l}\text { Perawatan tempat pendulangan } \\
\text { garam }\end{array}$ & & \\
Sumber: Yunus, Ahmad, \& lbrahim(2017) & & \\
\hline
\end{tabular}

JURNAL KELAUTAN NASIONAL, Vol. 15, No 1, April 2020, Hal. 1-12 
kehidupan masyarakat dan dapat bermanfaat dalam strategi pengelolaan ekosistem mangrove.

Kawasan pesisir utara Jakarta merupakan salah satu ekosistem di Teluk Jakarta yang mengalami tekanan lingkungan. Tekanan tersebut salah satunya diakibatkan adanya penumpukan konsentrasi penduduk sebagai dampak dari perkembangan kawasan yang mengalami pertumbuhan berbagai sektor seperti pusat perdagangan, permukiman, pusat pemerintahan, rekreasi, pendidikan, dan lain-lain (Agus et al., 2014). Ekosistem Mangrove Angke Kapuk (MAK) sebagai salah satu ekosistem di pesisir utara Jakarta yang masih tersisa dan memiliki sejumlah jasa ekosistem, saat ini menghadapi potensi ancaman degradasi sehingga sangat penting untuk mengetahui kondisinya. Penelitian ini bertujuan menganalisis kondisi kawasan ekosistem MAK dan konsekuensinya terhadap jasa ekosistem.

\section{BAHAN DAN METODE}

\section{Lokasi Penelitian}

Penelitian dilakukan di kawasan ekosistem MAK Teluk Jakarta Propinsi DKI Jakarta dengan batasan koordinat $6^{\circ} 05^{\prime} 20^{\prime \prime}-6^{\circ} 07^{\prime} 40^{\prime \prime}$ LS dan $106^{\circ} 43^{\prime} 00^{\prime \prime}-106^{\circ} 48^{\prime} 00^{\prime \prime}$ BT seperti pada Gambar 1.

\section{Sumber data dan alat}

Data yang digunakan adalah data citra satelit SPOT Interpretasi citra satelit (BIG 2014) menggunakan
6 Tahun 2016 dari Lembaga Penerbangan dan Antariksa Nasional (LAPAN) dengan spesifikasi citra multispektral (4 band), pancromatik dengan resolusi spasial 1,5 $\mathrm{m}$ yang telah terkoreksi geometrik dan radiometrik, Peta Rupa Bumi Indonesia (RBI) 1 : 25.000 Kecamatan Penjaringan Jakarta Utara tahun 2016. Peralatan yang digunakan adalah seperangkat komputer dengan aplikasi pengolahan citra dan Sistem Informasi Geografi (SIG), GPS dan Kamera. Observasi lapangan dan wawancara dilakukan terhadap pihak terkait seperti Balai Konservasi Sumber Daya Alam (BKSDA), Pengelola Hutan Lindung Angke Kapuk dan Taman Wisata Alam Angke Kapuk. Data lainnya diperoleh dari hasil riset, laporan, dan data terkait lainnya.

\section{Metodologi}

Ekosistem mangrove merupakan objek yang dapat diidentifikasi dengan penginderaan jauh dan memiliki karakterisik perekaman khas yaitu berada di daerah peralihan darat dan laut (Hernandi et al., 2013), dan vegetasi mangrove memiliki zat hijau daun (klorofil) (Wijaya et al., 2017). Penginderaan jauh telah banyak digunakan dalam studi ekosistem mangrove (Ardiansyaha \& Buchori 2014; Jia et al., 2016; Malik et al., 2017; Mondal et al., 2018). Penelitian ini dilakukan dengan tahapan seperti pada Gambar 2.

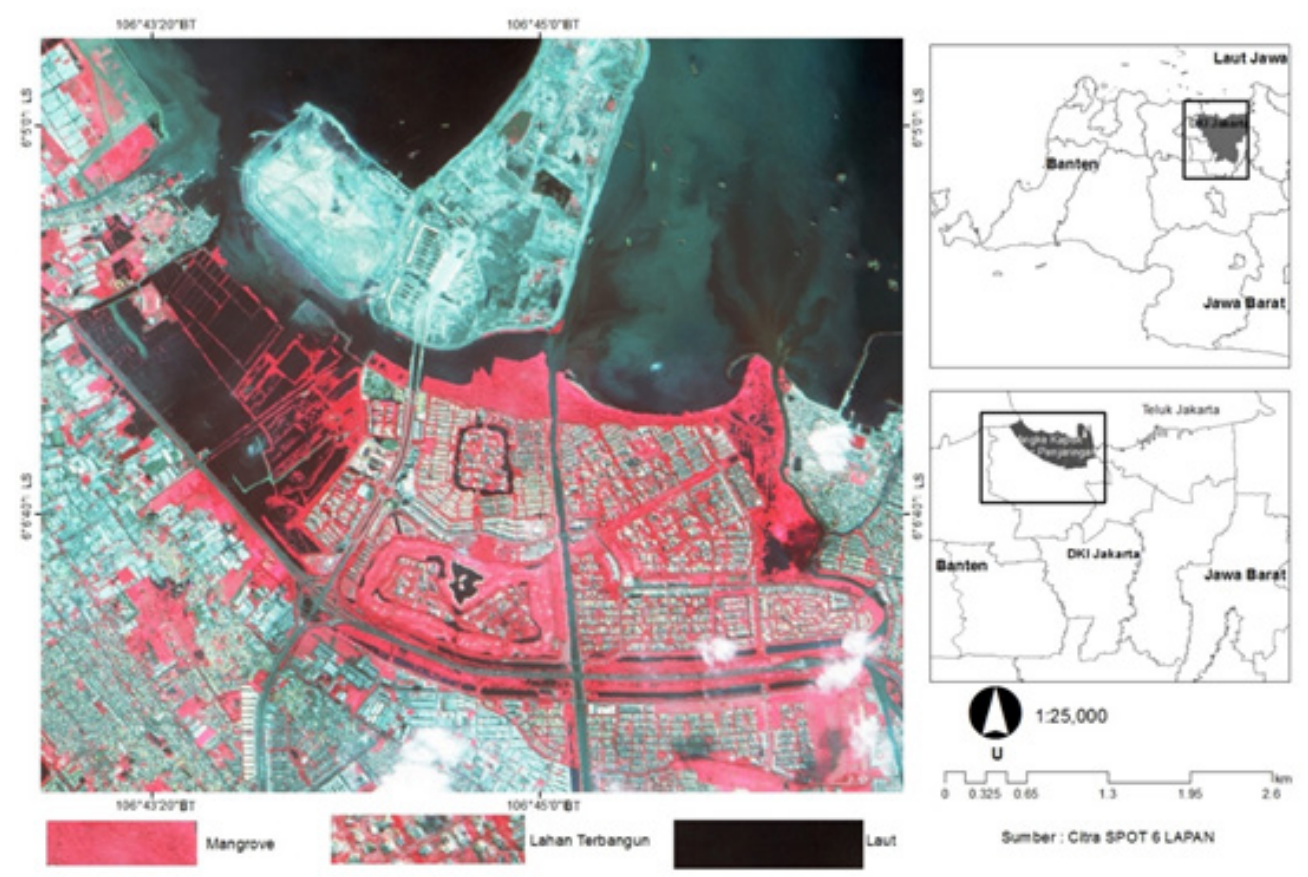

Gambar 1. Lokasi Penelitian (Citra SPOT 6) Figure 1. Study sites 


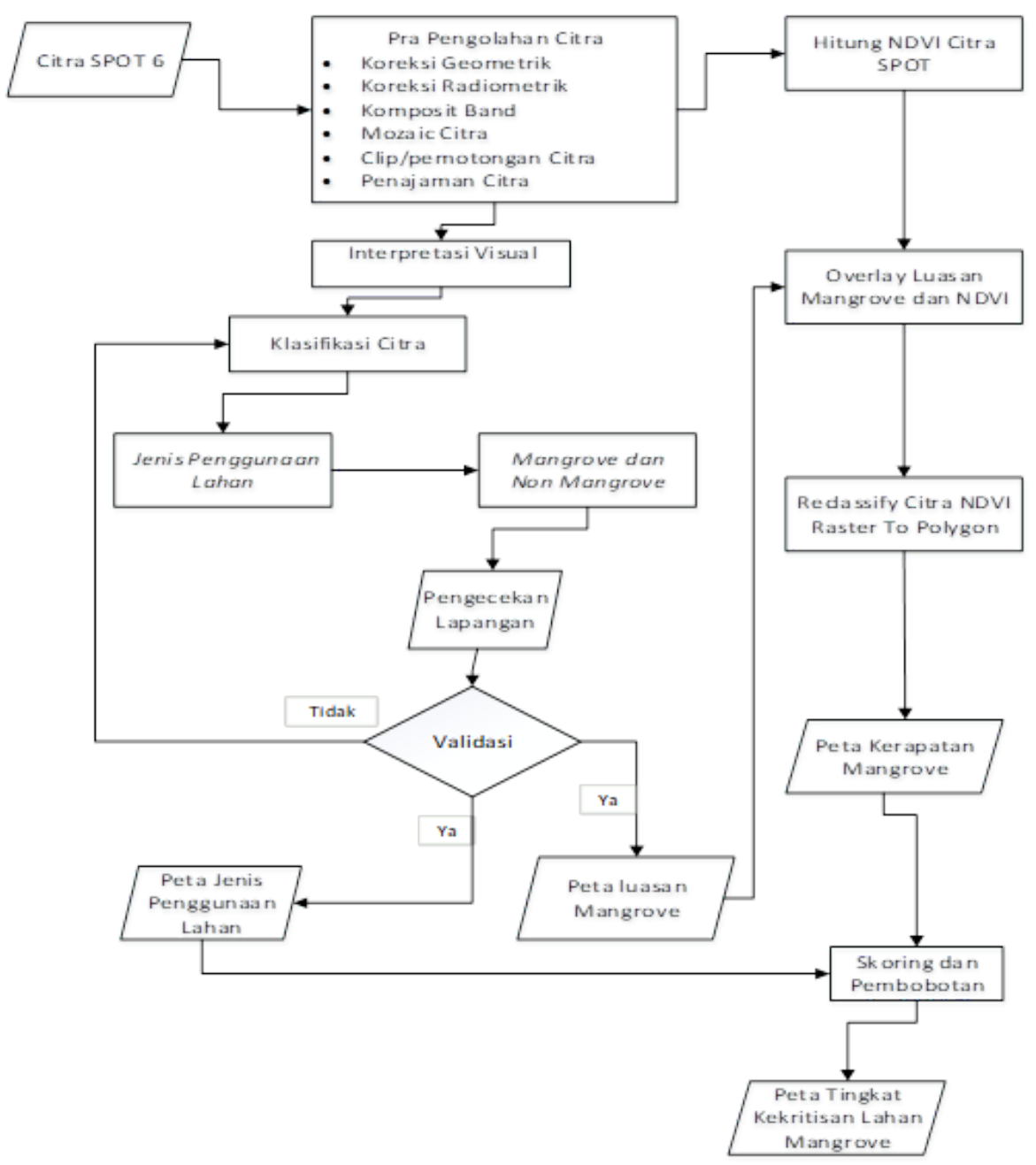

Gambar 2. Tahapan penelitian

Figure 2. Research steps

metode interpretasi visual (manual) dan outputnya berupa data vektor. Jumlah sampel secara proporsional mengacu pada Peraturan Kepala Badan Informasi Geospasial No 3 Tahun 2014. Uji akurasi dilakukan dengan pengamatan area sampel di lapangan, hasil penelitian sebelumnya atau data sekunder dari instansi terkait (LAPAN, 2015). Validasi lapangan dilakukan untuk memperoleh tingkat akurasi sebaran mangrove dari citra satelit. Ploting sample pada citra satelit kemudian dilakukan survei lapangan pada wilayah ekosistem mangrove dan sekitarnya. Validasi dilakukan menggunakan matriks akurasi, akurasi keseluruhan (overall accuracy) dan koefisien kappa (Jia et al., 2016; Mondal et al., 2018; Rudiastuti et al., 2018).

Interpretasi citra SPOT 6 menghasilkan peta luasan dan sebaran ekosistem mangrove. Hasil pemrosesan citra SPOT 6 kemudian diolah menggunakan software pengolah citra dan SIG untuk menghitung indeks vegetasi Normalized Difference Vegetation Index (NDVI). Indeks vegetasi merupakan perhitungan citra yang digunakan untuk mengetahui tingkat kehijauan vegetasi suatu wilayah melalui pengukuran optis tingkat kehijauan kanopi vegetasi, sifat komposit klorofil daun, dan tutupan kanopi vegetasi (Hernandi et al., 2013; Irawan \& Malau, 2016; Damayanti et al., 2017). Nilai NDVI diperoleh melalui persamaan (Hernandi et al., 2013; Irawan \& Malau, 2016) :

$$
N D V I=\left(\frac{N I R-R e d}{N I R+R e d}\right)
$$

dimana,

NDVI $=$ Normalized Difference Vegetation Index

NIR = Band near infrared (infra merah dekat)

Red $\quad=$ Band Red (merah)

Hasil perhitungan NDVI pada citra SPOT kemudian dilakukan reclassify sesuai dengan kelas tutupan mangrove mengacu kelas kerapatan tajuk dari Departemen Kehutanan (2005). Proses selanjutnya dengan menggabungkan peta tutupan mangrove dengan 
peta jenis penggunaan lahan. Informasi ketahanan tanah terhadap abrasi diperoleh dari peta landsystem, studi literatur dan peta Daya Dukung Lingkungan Hidup (D3TLH) Muara Angke Kapuk Teluk Jakarta tahun 2018 dari P3M Ekoregion Jawa Kementrian Lingkungan Hiduo dan Kehutanan (KLHK), serta studi Hamzah \& Setiawan (2010). Total nilai skoring (TNS) diperoleh dengan melakukan skoring dan pembobotan untuk masing-masing kriteria. Kriteria, bobot dan skor penilaian untuk penentuan tingkat kekritisan lahan mangrove dengan GIS dan Inderaja (Dephut, 2005) disajikan seperti dalam Tabel 2.

Total nilai skoring (TNS) dihitung dengan rumus sebagai berikut:

$$
T N S=(J p l \times 45)+(K t \times 35)+(K t a \times 20)
$$

Dari TNS, selanjutnya dapat ditentukan tingkat kekritisan lahan mangrove sebagai berikut:

- Nilai 100 - 166: rusak berat

- Nilai 167 - 233: rusak

- Nilai 234 - 300: tidak rusak

Hasil tingkat kekritisan lahan mangrove digunakan untuk menganalisis kondisi ekosistem dan konsekuensinya terhadap jasa ekosistem mangrove. Konsekuensi terhadap jasa ekosistem dijelaskan secara deskriptif dengan mengacu pada kondisi yang terjadi pada kawasan ekosistem MAK.

\section{HASIL DAN PEMBAHASAN}

Teluk Jakarta memiliki luas $490 \mathrm{~km}^{2}$, dengan panjang pantai sekitar $40 \mathrm{~km}$ dan kedalaman rata-rata $15 \mathrm{~m}$, terletak di bagian utara metropolitan Jakarta dengan batas geografis tanjung Karawang di bagian timur dan Tanjung Pasir Tangerang dibagian barat (Koropitan et al., 2009). Berbagai sumberdaya laut dan pesisir tersebar di sepanjang garis pantai utara Jakarta hingga mencapai perairan Kepulauan Seribu Provinsi DKI Jakarta (Tussadiah \& Husrin, 2017). Pesisir utara DKI Jakarta terkategori dataran rendah dan dinamis karena daratannya juga dipengaruhi perairan laut Teluk Jakarta. Pesisir utara DKI Jakarta terdiri dari beragam ekosistem dan salah satu yang utama yaitu ekosistem mangrove. Ekosistem mangrove Teluk Jakarta di sepanjang pesisir utara Jakarta yang masih ada terletak dibagian barat yaitu kawasan ekosistem MAK. Kawasan tersebut termasuk ke dalam wilayah Kecamatan Penjaringan Jakarta Utara terutama mulai dari Kelurahan Kapuk Muara sampai Kelurahan Kamal Muara dan muara sungai Angke ujung barat Kelurahan Pluit. Ekosistem mangrove perlu dilestarikan karena memiliki kekayaan ekosistem tak ternilai dan berfungsi sebagai penyangga lingkungan di kawasan sekitarnya (Puslitbang SDLP, 2016).

Penggunaan lahan di Kecamatan Penjaringan Jakarta Utara terdiri dari area terbangun, area terbuka, hutan mangrove, rawa, tambak, dan tubuh air. Area terbangun yang mendominasi wilayah Kecamatan Penjaringan merupakan permukiman dan sejumlah fasilitas pendukung lainnya. Provinsi DKI Jakarta masih memiliki hutan mangrove meski relatif kecil dibandingkan total luasan wilayahnya. Hutan dan hutan kota Provinsi DKI Jakarta diketahui persentase luasannya hanya sekitar $1.66 \%$ dibanding jumlah luasan provinsinya (Dinas Lingkungan Hidup DKI

Tabel 1. Kriteria, bobot, dan skor penilaian tingkat kekritisan lahan mangrove Table 2. Criteria, weight, and score of the critical level of mangrove area

\begin{tabular}{|c|c|c|c|}
\hline No & Kriteria & Bobot & Skor Penilaian \\
\hline 1 & Jenis penggunaan lahan $(\mathrm{Jpl})$ & 45 & $\begin{array}{l}\text { a. 3:hutan (kawasan berhutan) } \\
\text { b. 2:tambak tumpangsari, perkebunan } \\
\text { c. 1:permukiman, industri, tambak non-tumpangsari, } \\
\text { sawah, tanah kosong }\end{array}$ \\
\hline 2 & Kerapatan tajuk (Kt) & 35 & $\begin{array}{l}\text { a. } 3 \text { : kerapatan tajuk lebat }(70-100 \% \text {, atau } \\
0,43=<\text { NDVI }=<1 \\
\text { b. } 2: \text { kerapatan tajuk sedang }(50-69 \% \text {, atau } \\
\text { 0.,3 }=<\text { NDVI }=<0,42 \\
\text { c. } 1: \text { kerapatan tajuk jarang }(<50 \% \text {, atau } \\
-1,0=<\text { NDVI }=<0,32\end{array}$ \\
\hline 3 & $\begin{array}{l}\text { Ketahanan tanah terhadap } \\
\text { abrasi (Kta) }\end{array}$ & 20 & $\begin{array}{l}\text { a. } 3 \text { : jenis tanah tidak peka erosi (tekstur lempung) } \\
\text { b. } 2 \text { : jenis tanah peka erosi (tekstur campuran) } \\
\text { c. 1: jenis tanah sangat peka erosi (tekstur pasir) }\end{array}$ \\
\hline
\end{tabular}

Sumber: Dephut, 2005 
Jakarta, 2016). Hutan mangrove tersebar baik di pesisir utara Jakarta maupun di Kepulauan Seribu. Hutan mangrove yang ada di Provinsi DKI Jakarta terdiri dari Kawasan Suaka Margasatwa Muara Angke (SMMA), Kawasan Taman Wisata Alam (TWA) Angke Kapuk, Kawasan ekosistem mangrove tol Sedyatmo, Hutan Lindung Angke Kapuk (HLAK), Kebun bibit Angke Kapuk, dan wilayah Kepulauan Seribu yaitu Cagar Alam Pulau Bokor, Suaka Margasatwa Pulau Rambut, Pulau Penjaliran Timur, Penjaliran Barat (BPLHD DKI Jakarta, 2015). Status pengelolaan kawasan ekosistem MAK terdiri dari multi pihak dengan kondisi seperti pada Gambar 3. SMMA dikelola oleh Balai Konservasi Sumber Daya Alam (BKSDA) DKI Jakarta KLHK, Hutan Lindung Angke-Kapuk, dan Ekowisata Mangrove Tol Sedyatmo yang dikelola oleh Provinsi DKI Jakarta. TWA Angke Kapuk dibawah kewenangan BKSDA DKI Jakarta dengan izin kelola oleh swasta.

\section{Validasi dan akurasi}

Validasi dilakukan untuk memperoleh akurasi peta yang dihasilkan. Validasi data melalui survei lapangan dilakukan pada bulan April-Juli 2018 di Kawasan ekosistem MAK. Objek yang diamati terdiri dari vegetasi mangrove dan non mangrove. Titik sampling tersebar pada ekosistem MAK, mulai dari TWA Angke Kapuk, HLAK, SMMA, ekowisata mangrove tol Sedyatmo, sekitar Muara Angke dan Pantai Indah Kapuk (PIK). Hasil pengamatan lapang sebanyak 54 titik diperoleh kesesuaian dengan objek mangrove sebanyak 38 buah dan objek non-mangrove sebanyak 11 buah. Validasi dilakukan terhadap peta persebaran tutupan vegetasi hasil klasifikasi multispektral. Hasil uji ketelitian klasifikasi diperoleh akurasi keseluruhan sebesar $90.74 \%$ dan statistik kappa sebesar $75 \%$ yang menunjukkan informasi sebaran ekosistem mangrove cukup memadai.

\section{Luasan Mangrove dan Kondisi Sebaran}

Analisis visual dapat dilakukan dan menetapkan kombinasi RGB yang memiliki kemampuan lebih tinggi dalam mendeteksi objek khususnya mangrove (Forestian et al., 2011). Analisis visual citra SPOT 6 menggunakan kombinasi RGB 432 (Vo et al., 2013) menghasilkan informasi sebaran vegetasi baik mangrove dan non-mangrove di kawasan ekosistem MAK berwarna merah seperti pada peta lokasi penelitian (Gambar 1). Tutupan lahan sekitar kawasan MAK terlihat beragam dan didominasi oleh tutupan non vegetasi mangrove seperti bangunan permukiman dan tubuh air. Berdasarkan hasil interpretasi citra satelit SPOT 6, luasan ekosistem mangrove kawasan MAK sebesar 291,17 ha. Keterbatasan jumlah band yang dimiliki SPOT menyebabkan pemanfaatan datanya terbatas dalam indeks non vegetasi lainnya seperti penentuan tubuh air dan bangunan (Febrianti et al., 2015). Keberadaan vegetasi mangrove masih terlihat di sepanjang pantai utara Jakarta terutama di SMMA, HLAK, dan TWA Angke Kapuk. Mangrove Angke Kapuk tersebar di sekeliling PIK mulai dari Muara Angke sepanjang sungai Angke menuju Teluk Jakarta di sebelah timur, pesisir sebelah utara PIK, TWA Angke Kapuk dan sepanjang tol Sedyatmo di sebelah selatan.

Ekosistem mangrove yang masih terlihat terjaga sebagian besar berada pada kawasan SMMA dan HLAK, meskipun demikian, posisinya sangat dekat dan berada diantara kawasan permukiman dan infrastruktur lainnya. Luasan mangrove yang masih ada di kawasan ekosistem MAK sangat penting untuk dijaga. Menurut Lisna et al. (2017) luasan kawasan mangrove sangat penting karena dapat menentukan keanekaragam spesies, memungkinkan mangrove untuk tumbuh dan mengurangi kompetisi antar spesies dengan adanya ruang yang cukup, dan terjadi pertukaran genetik dalam populasi luas, serta berpotensi mengurangi gangguan aktivitas manusia dalam memanfaatkan

Kawasan Mangrove Angke Kapuk Teluk Jakarta
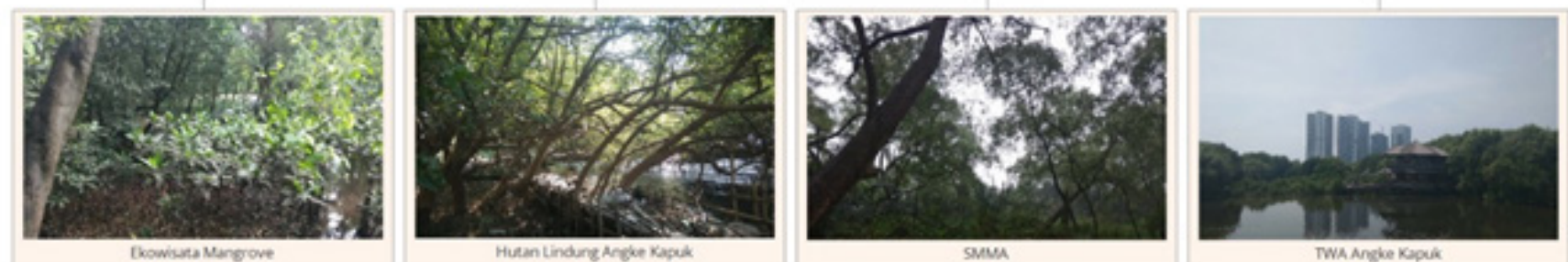

Gambar 3. Kawasan ekosistem MAK. Figure 3. MAK ecosystem area.

JURNAL KELAUTAN NASIONAL, Vol. 15, No 1, April 2020, Hal. 1-12 
kawasan mangrove.

\section{Indeks Vegetasi}

Indeks vegetasi digunakan untuk menganalisis tutupan vegetasi mangrove. Indeks vegetasi NDVI dapat merepresentasikan tingkat kehijauan mangrove di kawasan ekosistem MAK seperti disajikan pada Gambar 4. Mangrove tersebar mengelilingi komplek PIK dan sepanjang tol Sedyatmo. Nilai indeks NDVI kawasan ekosistem MAK dikategorikan jarang, sedang dan lebat. Kerapatan mangrove didominasi kategori jarang 272,79 ha, sementara yang terkategori sedang 16,83 ha dan lebat 1,54 ha. Kondisi mangrove di kawasan SMMA dan HLAK terdapat mangrove yang terkategori sedang dan lebat, sedangkan mangrove di sepanjang tol Sedyatmo dan TWA Angke Kapuk terkategori jarang dan sedikit yang sedang. Kerapatan mangrove yang didominasi kategori jarang tersebut sama dengan penelitian Hilmi et al. (2017) yang menyebutkan ekosistem mangrove Jakarta terkategori jarang hingga sedang, sementara hasil penelitian Mayalanda et al. (2014) di SMMA menyebutkan kerapatan vegetasi mangrove di kawasan tersebut berdasarkan analisis vegetasi tergolong tingkat kerapatan jarang.

Vegetasi mangrove di kawasan ekosistem MAK relatif homogen (DLH DKI Jakarta, 2016), beberapa spesies mangrove yang tumbuh antara lain Aviecennia $s p$,
Rhizopora sp, dan Sonneratia sp. Jenis-jenis tersebut banyak dijumpai di kawasan ekosistem MAK dan merupakan jenis mangrove yang banyak ditanam dalam upaya rehabilitasi. Menurut Hilmi et al. (2017) spesies mangrove Rhizophora apiculata, Rhizophora mucronata, Avicennia alba dan Sonneratia alba mendominasi wilayah utara Jakarta karena spesies tersebut memiliki toleransi yang tinggi terhadap sampah, limbah rumah tangga, minyak, logam berat dan genangan air laut. Berdasarkan peta D3TLH, kawasan ekosistem MAK memiliki jenis tanah fluvio marin alluvium dan substrat ekosistem mangrove di Muara Angke merupakan campuran liat, debu, dan pasir (Hamzah \& Setiawan, 2010). Kawasan ekosistem MAK masih memiliki manfaat dan jasa ekosistem seperti pelindung pantai dari abrasi dan sebagai tempat wisata. Luasan ekosistem MAK yang tersisa tersebut menjadi sangat berharga dan memiliki nilai sejarah seperti Suaka Marga Muara Angke (SMMA) dengan keanekaragaman hayatinya.

\section{Tingkat Kekritisan Lahan Mangrove}

Identifikasi jenis penggunan lahan, kerapatan tajuk, dan ketahanan tanah di kawasan ekosistem MAK Kecamatan Penjaringan Jakarta Utara digunakan untuk menilai tingkat kekritisan lahan mangrove. Hasil analisis tingkat kekritisan lahan mangrove seperti pada Gambar 5 menunjukkan kawasan ekosistem

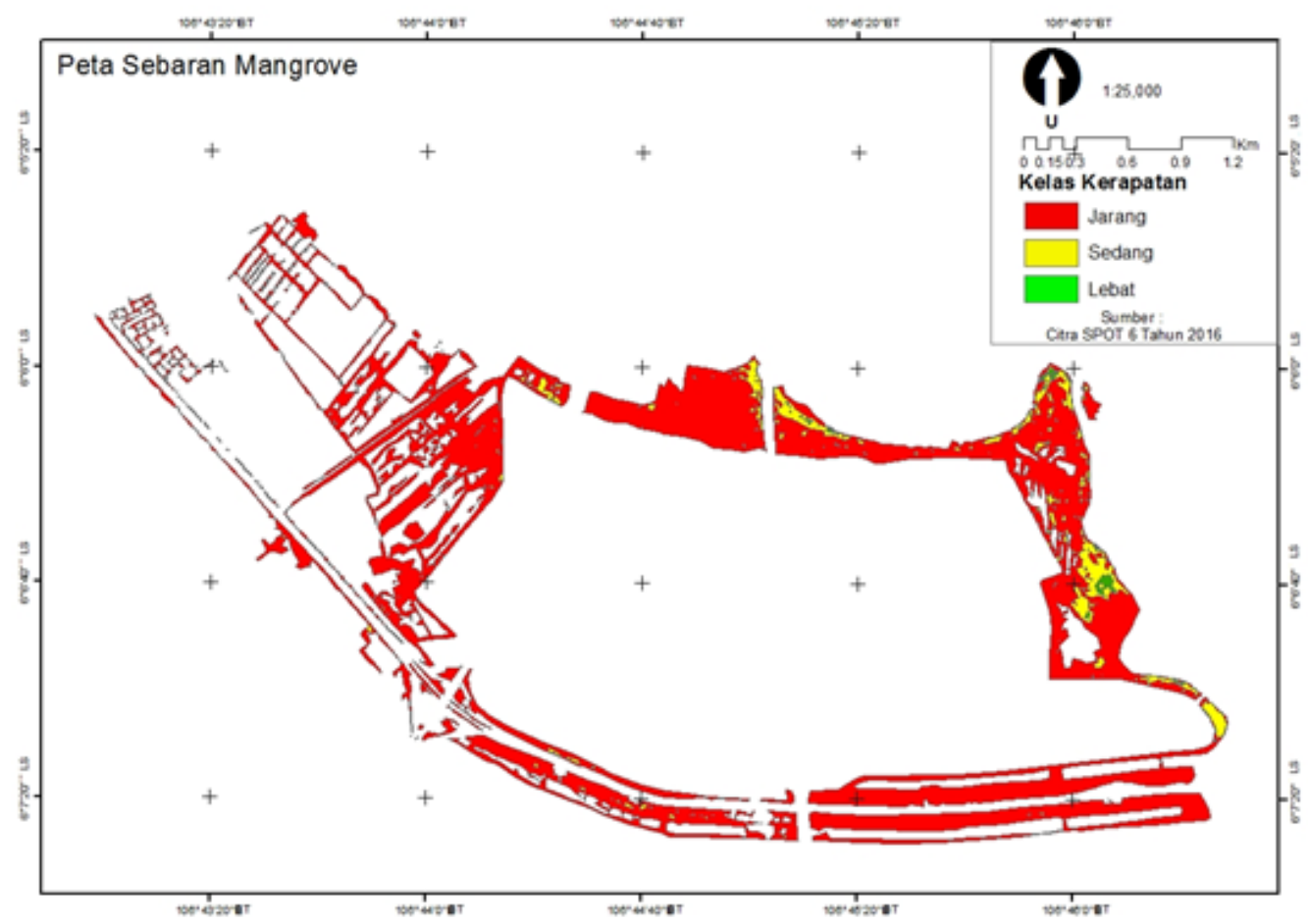

Gambar 4. Sebaran Kerapatan Mangrove.

Figure 4. Distribution of mangrove density. 
MAK memiliki tingkat kekritisan terkategori rusak sekitar 272,79 ha dan hanya sebagian kecil terkategori tidak rusak yaitu sekitar 18,38 ha. Tingkat kekritisan lahan mangrove yang terkategori rusak berat karena lahan mangrovenya berupa rawa, tambak atau sudah dikonversi menjadi area terbangun seperti permukiman dan lainnya. Secara historis kawasan ekosistem MAK mengalami perubahan yang besar terutama sejak pembukaan tambak besar-besaran, kemudian pengembangan bandara dan jalan tol serta pengembangan dan pembangunan kawasan termasuk untuk perumahan, dan lainnya (Mayalanda et al., 2014).

Ekosistem MAK secara umum memiliki keterbatasan penyebaran, kerapatan yang jarang, spesies yang relatif homogen seperti Aviecennia sp, Rhizopora $s p$, dan Sonneratia $s p$, serta kondisi ekosistem yang cukup mengkhawatirkan. Kondisi tersebut terutama akibat pemanfaatan ekosistem yang berlebihan oleh manusia. Aktivitas manusia (antropogenik) telah menimbulkan dampak baik langsung maupun tidak langsung terhadap ekosistem MAK. Hilmi et al. (2017) menyebutkan faktor terbesar penyebab degradasi ekosistem mangrove di Jakarta karena konversi lahan mangrove menjadi permukiman dan aktivitas lainnya. Studi Chung et al. (2015) di Korea Selatan juga menyebutkan dampak urbanisasi dan industri telah menyebabkan degradasi habitat dan hilangnya keanekaragaman hayati di wilayah pesisir.
Area terbangun yang mendominasi kawasan ekosistem MAK dapat meningkatkan tekanan keberadaan ekosistem mangrove yang masih bervegetasi. Tekanan tersebut dapat semakin meningkat dengan pencemaran yang berasal dari limbah aktivitas antropogenik di area terbangun. Yusuf et al. (2017) yang mengkaji kontribusi faktor antropogenik terhadap deforestasi mangrove di Konawe Selatan Sulawesi Tenggara menyebutkan bahwa aktivitas manusia menjadi faktor yang paling mengancam keberadaan ekosistem mangrove melalui kedekatan akses seperti jarak dari permukiman dan jalan utama, kegiatan tambak budidaya, dan status penunjukan kawasan hutan.

Tekanan antropogenik yang ada di sekitar kawasan ekosistem MAK juga berasal dari kegiatan reklamasi dan sampah plastik. Kegiatan reklamasi Teluk Jakarta di pesisir utara kawasan ekosistem MAK juga menambah dinamika kondisi ekosistem mangrove yang terjadi. Pulau buatan yang dibangun didepan hutan mangrove dapat mengubah hidrodinamika pesisir sehingga mengubah salinitas dan karakteristik pasang surut (Pusriskel KKP, 2017). Chung et al. (2015) menyebutkan kegiatan reklamasi pesisir di Korea Selatan telah menurunkan habitat alami dan menjadi pendorong utama hilangnya keanekaragaman hayati. Perairan di sekitar ekosistem MAK sejak dilakukan kegiatan reklamasi menjadi lebih gelap dan kotor akibat sirkulasi perairan dari laut yang terhalang oleh

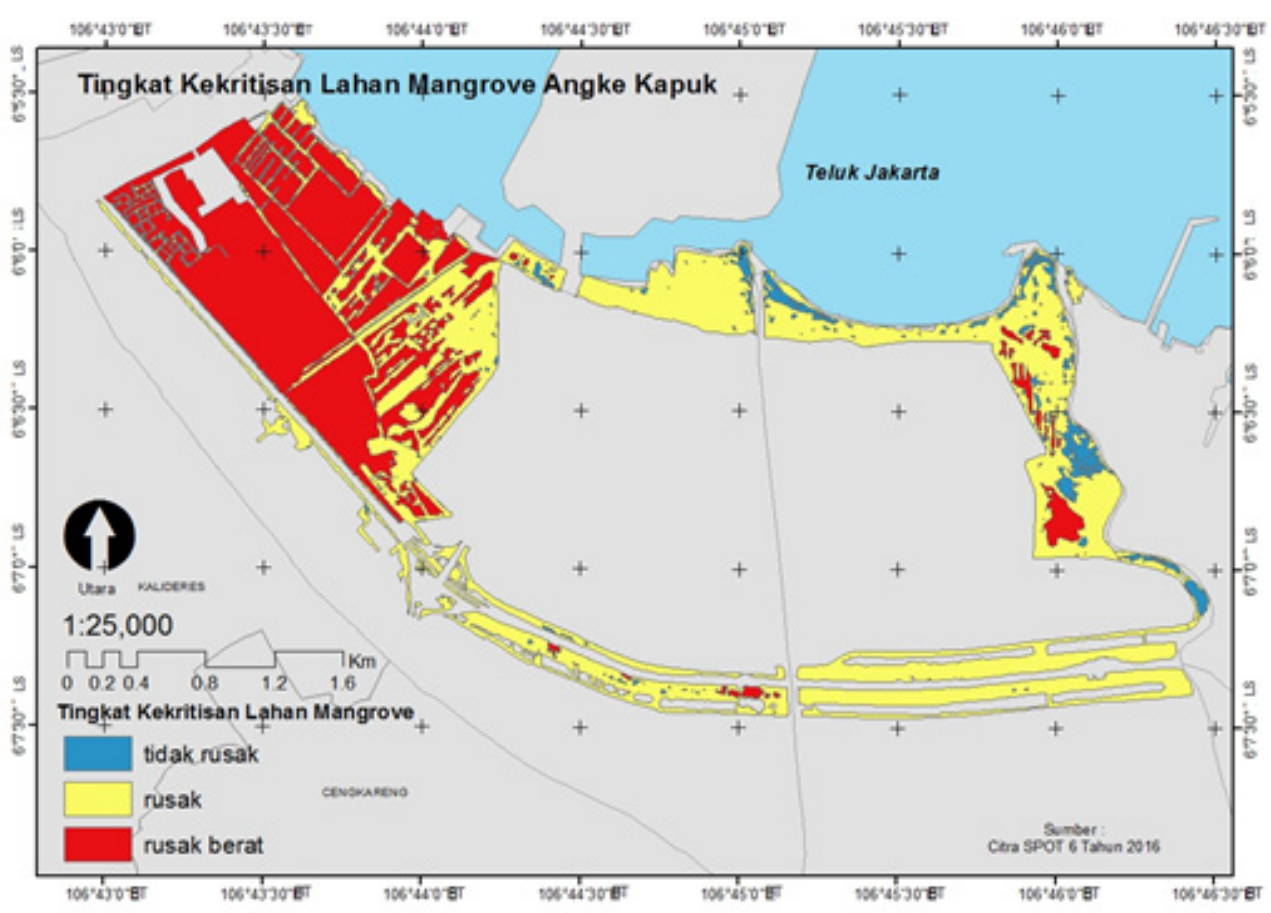

Gambar 5. Tingkat kekritisan lahan mangrove kawasan MAK.

Figure 5. The critical level of mangrove area of MAK. 
pulau reklamasi. Sampah plastik didasar perairan juga cukup mengganggu konservasi ekosistem mangrove karena dapat mengurangi kekuatan perakaran mangrove yang tumbuh. Kondisi yang berlangsung secara terus menerus tersebut dapat menimbulkan ketidakseimbangan dan menyebabkan degradasi ekosistem. Kondisi tersebut juga akan berkonsekuensi terhadap menurunnya jasa ekosistem yang tersedia, sementara pertumbuhan populasi penduduk yang terus terjadi justru akan meningkatkan permintaan terhadap jasa ekosistem.

\section{Konsekuensi terhadap jasa ekosistem}

Sejumlah manfaat dan jasa (services) ekosistem MAK masih dirasakan meski terbatas. Jasa ekosistem mangrove sangat penting bagi masyarakat sekitar dan memiliki dimensi budaya dan ekologi juga aspek ekonomi (Vo et al., 2015), sementara kondisi yang terjadi pada ekosistem MAKakanmemilikikonsekuensi terhadap jasa ekosistem baik jasa penyediaan, jasa pengaturan dan perawatan, maupun jasa budaya. Jasa ekosistem mangrove yang sediakala masih dirasakan menjadi semakin berkurang atau bahkan hilang sehingga pada akhirnya dapat menyebabkan ketidaknyamanan, kerugian ekonomi, dan ancaman bencana. Jasa penyediaan pangan seperti ikan yang bernilai ekonomi tinggi sudah sulit didapatkan. Jasa pengaturan berupa perlindungan pantai menjadi hilang terutama disepanjang pantai yang tidak memiliki sabuk hijau mangrove lagi. Jasa perlindungan dari intrusi air laut juga semakin berkurang, begitupun jasa budaya berupa nilai keindahan dan spiritual. Intrusi air laut juga menyebabkan pencemaran air tanah sehingga tidak dapat digunakan masyarakat. Ekosistem MAK yang terpisah oleh kawasan permukiman PIK dan jalan tol juga dapat berdampak terhadap jasa ekosistemnya. Brander et al. (2012) menyebutkan bahwa pemisahan area mangrove dan wilayah sekitarnya melalui pembangunan jalan memiliki dampak negatif terhadap nilai jasa ekosistem mangrove.

Ekosistem MAK yang masih ada tak lepas dari perhatian dan kepedulian dari berbagai pihak baik pemerintah, maupun masyarakat. Pengelolaan ekosistem MAK telah melibatkan multi pihak baik pemerintah pusat dan daerah, swasta, LSM dan masyarakat. Ekosistem MAK memiliki manfaat dan peran dalam perlindungan pantai dari intrusi air laut dan abrasi. Ekosistem mangrove TWA Angke Kapuk yang dikelola sebagai objek wisata memberikan jasa ekosistem berupa keindahan dan banyak diminati oleh masyarakat untuk rekreasi maupun pembelajaran. Hal tersebut dapat menjadi potensi yang dapat meningkatkan dukungan dan kesadaran terhadap pentingnya jasa ekosistem mangrove. SMMA juga berperan dalam menjaga kelestarian satwa disamping keanearagaman hayati mangrove dan jasa ekosistem lainnya. Hasil pengamatan di lapangan menunjukkan masih terdapat sejumlah satwa seperti monyet ekor panjang (Macaca fascicularis) dan biawak air (Varanus salvator) yang menjadikan ekosistem MAK sebagai habitatnya. Kondisi tersebut juga membuka peluang untuk terus melakukan upaya konservasi dan perlindungan terhadap ekosistem mangrove. Keberadaan kawasan ekosistem MAK di pesisir utara DKI Jakarta perlu mendapat perhatian karena masih memberikan jasa ekosistem yang dirasakan masyarakat dan berperan penting dalam menjaga kelestarian lingkungan. Upaya rehabilitasi dan konservasi perlu terus dilakukan dengan memperhatikan kesesuaian jenis dan kondisi lingkungan sehingga ketersediaan sumberdaya dan jasa ekosistemnya bisa ditingkatkan.

\section{KESIMPULAN DAN SARAN}

Penggunaan lahan kawasan ekosistem MAK dan sekitarnya di Kecamatan Penjaringan Jakarta Utara terdiri dari area terbangun, area terbuka, hutan mangrove, rawa, tambak, dan tubuh air. Kerapatan mangrove berdasarkan nilai indeks NDVI terkategori jarang 272,79 ha, sedang 16,83 ha dan lebat 1,54 ha. Kondisi kawasan ekosistem MAK berdasarkan tingkat kekritisan lahan mangrove terkategori rusak 272,79 ha dan terkategori tidak rusak 18,38 ha. Kawasan ekosistem MAK juga berpotensi terus mengalami tekanan terutama disebabkan aktivitas dari area terbangun di sekitarnya dan penggunaan lainnya. Kondisi tersebut juga akan berkonsekuensi terhadap menurunnya jasa ekosistem yang tersedia. Jasa ekosistem mangrove yang sediakala masih dirasakan menjadi semakin berkurang atau bahkan hilang sehingga pada akhirnya dapat menyebabkan berkurangnya penyediaan sumber pangan perikanan, menurunnya keanearagaman hayati, ketidaknyamanan, kerugian ekonomi, ancaman bencana, dan berkurangnya keindahan. Keberadaan kawasan ekosistem mangrove di pesisir Jakarta perlu mendapat perhatian karena masih berkontribusi memberikan jasa ekosistem dan menjaga kelestarian lingkungan. Saran untuk penelitian selanjutnya dapat mengggunakan citra satelit beresolusi tinggi untuk meningkatkan akurasi hasil dan mengidentifikasi masing-masing jasa ekosistem mangrove secara lebih mendalam. 


\section{UCAPAN TERIMA KASIH}

Penulis mengucapkan terima kasih atas dukungan dan bantuan kepada Pusat Pendidikan KP Badan Riset dan SDM Kelautan Perikanan KKP, LAPAN, PPLH IPB, BKSDA DKI Jakarta, KLHK, KKP, Pemerintah Provinsi DKI Jakarta, Pengelola TWA Angke Kapuk, dan pihak-pihak lainnya.

\section{DAFTAR PUSTAKA}

Agus, D., Kusmana, C., \& Ramadan, H. (2014). Strategi pengelolaan hutan lindung angke kapuk. Jurnal Pengelolaan Sumberdaya Alam Dan Lingkungan, 4(1), 35-42.

Ahmed, N., \& Glaser, M. (2016). Coastal aquaculture, mangrove deforestation and blue carbon emissions: Is REDD+ a solution? Marine Policy, 66, 58-66. http://doi.org/10.1016/j.marpol.2016.01.011.

Ardiansyaha, D. A., \& Buchori, I. (2014). Pemanfaatan Citra Satelit Untuk Penentuan Lahan Kritis Mangrove Di Kecamatan Tugu, Kota Semarang. Geoplanning, $1(1), 1-12$.

[BPLHD DKI Jakarta] Badan Pengelolaan Lingkungan Hidup Daerah DKI Jakarta. (2015). Status lingkungan hidup daerah provinsi daerah khusus ibukota Jakarta tahun 2015.

[BIG] Badan Informasi Geosapasial. (2014). Peraturan kepala badan informasi geospasial nomor 3 tahun 2014 tentang pedoman teknis pengumpulan dan pengolahan data geospasial mangrove.

Brander, L. M., Wagtendonk, A. J., Hussain, S. S., McVittie, A., Verburg, P. H., de Groot, R. S., \& van der Ploeg, S. (2012). Ecosystem service values for mangroves in Southeast Asia: A meta-analysis and value transfer application. Ecosystem Services, 1(1), 62-69. http:// doi.org/10.1016/j.ecoser.2012.06.003.

Chung, M. G., Kang, H., \& Choi, S. (2015). Assessment of coastal ecosystem services for conservation strategies in South Korea. PLoS ONE, 10(7), 1-23. http://doi.org/10.1371/journal.pone.0133856.

Damayanti, I. R., Wijaya, N. I., \& Patwati, E. (2017). Perubahan luas dan kerapatan ekosistem mangrove di pantai Surabaya. Seminar Nasional Kelautan XII "Inovasi Hasil Riset dan Teknologi dalam Rangka Penguatan Kemandirian Pengelolaan Sumber Daya Laut dan Pesisir" Fakutaltas Teknik dan Ilmu Kelautan Universitas Hang Tuah, Surabaya 20 Juli 2017 (pp. 102-108).

[Dephut] Departemen Kehutanan. (2005). Pedoman inventarisasi dan identifikasi lahan kritis mangrove.

[DLH DKI Jakarta] Dinas Lingkungan Hidup DKI Jakarta. (2016). Dokumen informasi kinerja pengelolaan lingkungan hidup daerah provinsi DKI Jakarta tahun 2016.

Elliff, C. I., \& Kikuchi, R. K. P. (2015). The ecosystem service approach and its application as a tool for integrated coastal management. Natureza \& Conservação, 13(2), 105-111.

Febrianti, N., Pasaribu, J. M., \& Sulma, S. (2015). Analisis ruang terbuka hijau di DKI Jakarta menggunakan data spot 6. In Prosiding Pertemuan Ilmiah Tahunan XX 2015 (pp. 644-649).

Forestian, O., Prasetyo, L. B., \& Kusmana, C. (2011). Estimasi biomassa dan kepadatan vegetasi mangrove mengunakan Landsat ETM+: Kasus Hutan Lindung Muara Gembong, Bekasi, Jawa Barat. Bonorowo Wetlands, 2(December), 80-95. http://doi. org/10.13057/bonorowo/w01020

Friess, D. A., \& Webb, E. L. (2014). Variability in mangrove change estimates and implications for the assessment of ecosystem service provision. Global Ecology and Biogeography, 23(7), 715-725. http://doi. org/10.1111/geb.12140.

Hamilton, S. E., \& Casey, D. (2016). Creation of a high spatio-temporal resolution global database of continuous mangrove forest cover for the 21 st century (CGMFC-21). Global Ecology and Biogeograph, 25, 729-738. http://doi.org/10.1111/geb.12449

Hamzah, F., \& Setiawan, A. (2010). Akumuasi logam berat $\mathrm{Pb}, \mathrm{Cu}$, dan $\mathrm{Zn}$ di hutan mangrove Muara Angke, Jakarta Utara. Jurnal Ilmu Dan Teknologi Kelautan Tropis, 2(2), 41-52.

Hernandi, K., Sukojo, B. M., \& Parwati, E. (2013). Studi tingkat kerapatan mangrove menggunakan indeks vegetasi. Jurnal Teknik Pomits, 4(4), 1-6.

Hilmi, E., Kusmana, C., Suhendang, E., \& Iskandar. (2017). Correlation analysis between seawater intrusion and mangrove greenbelt. Indonesian Journal of Forestry Research, 4(2), 151-168. http://doi.org/10.20886/ ijfr.2017.4.2.151-168.

Irawan, S., \& Malau, A. O. (2016). Analisis persebaran mangrove di pulau batam menggunakan teknologi penginderaan jauh. Jurnal Integrasi, 8(2), 80-87.

Jia, M., Liu, M., Wang, Z., Mao, D., Ren, C., \& Cui, H. (2016). Evaluating the effectiveness of conservation on mangroves : a remote sensing-based comparison for two adjacent protected areas in Shenzhen and Hong Kong, China. Remote Sensing, 8(627), 1-20. http://doi.org/10.3390/rs8080627.

Koropitan, A. F., Ikeda, M., Damar, A., \& Yamanaka, Y. (2009). Influences of physical processes on the ecosystem of Jakarta Bay: a coupled physical ecosystem model experiment. ICES Journal of Marine Science, 2003, 336-348.

Kusmana, C. (2015). Integrated sustainable mangrove forest management. Jurnal Pengelolaan Sumberdaya Alam Dan Lingkungan, 5(1), 1-6.

[LAPAN] Lembaga Penerbangan dan Antariksa Nasional (2015). Pedoman pengolahan data penginderaan jauh landsat 8 untuk mangrove. Pusat Pemanfaatan Penginderaan Jauh LAPAN.

Lisna, Malik, A., \& Toknok, B. (2017). Potensi vegetasi hutan mangrove di wilayah pesisir pantai. Warta Rimba, 5, 63-70. 
Malik, A., Fensholt, R., \& Mertz, O. (2015). Mangrove exploitation effects on biodiversity and ecosystem services. Biodiversity and Conservation, 24(14), 3543-3557. http://doi.org/10.1007/s10531-0151015-4.

Malik, A., Mertz, O., \& Fensholt, R. (2017). Mangrove forest decline: consequences for livelihoods and environment in South Sulawesi. Regional Environmental Change, 17(1), 157-169. http://doi. org/10.1007/s10113-016-0989-0.

Mayalanda, Y., Yulianda, F., \& Setyobudiandi, I. (2014). Strategi rehabilitasi ekosistem mangrove melalui analisis tingkat kerusakan di Suaka Margasatwa Muara Angke. Bonorowo Wetlands, 4(June), 12-36.

Mondal, P., Trzaska, S., \& Sherbinin, A. (2018). Landsatderived estimates of mangrove extents in the Sierra Leone coastal landscape complex during 19902016. Sensors, 18(12), 1-15. http://doi.org/10.3390/ s18010012.

Omo-irabor, O. O., B, S., Olobaniyi, Akunna, J., Venus, V., Maina, J. M., \& Paradzayi, C. (2011). Mangrove vulnerability modelling in parts of Western Niger Delta, Nigeria using satellite images, GIS techniques and Spatial Multi-Criteria Analysis (SMCA). Environment Monitoring Assess, 178, 39-51. http:// doi.org/10.1007/s10661-010-1669-z.

[Puslitbang SDLP] Pusat Penelitian dan Pengembangan Sumber Daya Laut dan Pesisir. (2016). Laporan akhir dampak pengembangan NCICD pada desain hijau tanggul laut Jakarta.

Pusriskel KKP . Pusat Riset Kelautan KKP (2017). Laporan akhir kajian daya dukung \& keberlanjutan ekosistem untuk mendukung zona wisata bahari dan pembatasan reklamasi.

Rudiastuti, A. W., Yuwono, D. M., \& Hartini, S. (2018). Mangrove mapping using SPOT 6 at East Lombok Indonesia. In 3rd ICOIRS 2017.

Schmitt K, Duke NC. (2015). Mangrove Management , Assessment and Monitoring. Di dalam: Tropical Forestry Handbook. hlm. 1-29

Tussadiah, A., \& Husrin, S. (2017). Dinamika Teluk Jakarta tantangan dan rencana pengembangan kedepan. (R. Basuki, Ed.). Pusat Riset Kelautan Badan Riset dan Sumberdaya Manusia Kelautan dan Perikanan Kementerian Kelautan dan Perikanan.

Vo, Q. T., Oppelt, N., Leinenkugel, P., \& Kuenzer, C. (2013). Remote Sensing in Mapping Mangrove Ecosystems - An Object-Based Approach. Remote Sensing, 183201. http://doi.org/10.3390/rs5010183.

Vo, T.Q., Kuenzer, C., \& Oppelt, N. (2015). How remote sensing supports mangrove ecosystem service valuation: A case study in $\mathrm{Ca}$ Mau province, Vietnam. Ecosystem Services, 14, 67-75. http://doi. org/10.1016/j.ecoser.2015.04.007.

Wijaya, N. I., Damayanti, I. R., Patwati, E., \& Adawiah, S. W. (2017). Perubahan luas ekosistem mangrove di kawasan pantai timur. Prosiding Seminar Nasional Kelautan dan Perikanan III 2017 (pp. 70-74).
Yunus, M. Z. M., Ahmad, F. S., \& Ibrahim, N. (2017). Mangrove vulnerability index using GIS. In International Conference on Engineering and Technology (IntCET 2017) (pp. 1-9). AIP Publishing. Yusuf, D. N., Prasetyo, L. B., Kusmana, C., \& Machfud. (2017). Geospatial approach in determining anthropogenic factors contributed to deforestation of mangrove : A case study in Konawe Selatan, Southeast Sulawesi. In LISAT IOP Conf. Series: Earth and Environmental Science (pp. 1-10). IOP Publishing. http://doi. org/10.1088/1742-6596/755/1/011001. 
